\title{
PEMBERIAN DIET FORMULA 75 DAN 100 MENINGKATKAN BERAT BADAN BALITA GIZI BURUK RAWAT JALAN
}

\author{
Sulistiyawati $^{12^{* *}}$, Yeni Rustina ${ }^{3}$, Sutanto Priyo Hastono ${ }^{4}$ \\ 1. STIKES Bethesda Yakkum, Yogyakarta 55224, Indonesia \\ 2. Program Studi Magister Fakultas Ilmu Keperawatan Universitas Indonesia, Depok 16424, Indonesia \\ 3. Fakultas Ilmu Keperawatan Universitas Indonesia, Depok 16424, Indonesia \\ 4. Fakultas Kesehatan Masyarakat Universitas Indonesia, Depok 16424, Indonesia \\ *Email:jellistya@yahoo.com
}

\begin{abstract}
Abstrak
Gizi buruk balita masih menjadi permasalahan serius di Indonesia. Tujuan penelitian menjelaskan pengaruh pemberian diet formula 75 dan 100 terhadap berat badan balita gizi buruk rawat jalan. Desain penelitian quasi experimental pre-post test with control group dengan teknik total sampling, terdiri dari 15 responden kelompok intervensi dan 15 responden kelompok kontrol. Analisis yang digunakan adalah uji chi squere, paired t-test, independent t-test, uji ancova. Uji statistik menunjukkan perbedaan bermakna berat badan balita gizi buruk rawat jalan sebelum dan sesudah perlakuan pada kelompok intervensi dan kontrol ( $p=0,00 ; \alpha=0,05)$. Peningkatan berat badan kelompok intervensi lebih besar daripada kelompok kontrol. Puskesmas diharapkan menindaklanjuti hasil penelitian sehingga mencapai target berat badan balita gizi buruk rawat jalan sesuai standar.
\end{abstract}

Kata kunci: gizi buruk, rawat jalan, diet formula 75 dan 100

\begin{abstract}
Malnutrition in children is still a serious problem in Indonesia. This study aimed to describe the influence of diet formulas 75 and 100 to the body weight of under five years old malnutrition outpatient. Research design was quasi experimental pre-post test with control group. Total sampling technique was used to involve 15 respondents as intervention group and 15 respondents as control group. Data was analyzed using chi square, paired t-test, independent t-test, and ancova test. Thet results show that there were significant differences in the body weight before and after treatment in the intervention group and control group $(p=0.00 ; \alpha=0.05)$. The improvement of body weight on intervention group is greater than the control group. Public health centers are expected to follow up the results of this study as to reach the target of body weight of children under five years malnutrition outpatients according to the standard.
\end{abstract}

Keywords : malnutrition, outpatient, formula diet 75 and 100

\section{Pendahuluan}

Pembangunan Milenium (Millennium Development Goals, atau MDGs) mengandung delapan tujuan sebagai respon atas permasalahan perkembangan global, yang kesemuanya harus tercapai pada 2015. Salah satunya adalah memberantas kemiskinan ekstrim dan kelaparan, dengan target yang harus dicapai antara 1990 sampai 2015. Masalah gizi merupakan masalah kesehatan masyarakat yang penanggulangannya tidak dapat dilakukan dengan pendekatan medis dan pelayanan kesehatan saja.

Masalah gizi pada balita yang cukup besar dan harus mendapatkan prioritas penanganan adalah masalah gizi buruk. Keadaan gizi buruk pada balita akan menghambat peningkatan sumber daya manusia karena keadaan ini dapat mengakibatkan kegagalan pertumbuhan fisik dan perkembangan kecerdasan serta meningkatkan angka kesakitan dan kematian (Sajudi, 2000).

Depkes (2001) menyatakan indeks yang digunakan WHO untuk kategori severe malnutrition adalah berat badan menurut tinggi badan (BB/TB) dengan Z-skore $<-3,0$ yaitu kategori severe wasting (sangat kurus) atau gizi buruk yang disertai tanda klinis gizi buruk. Prevalensi balita sangat kurus di Indonesia pada 2001 adalah 5,9\% dari total yang termasuk kategori kurus dan sangat kurus 15,6\%. 
Proporsi tertinggi adalah pada kelompok umur 12 - 23 bulan dengan 8,2\% untuk kategori sangat kurus. Depkes (2008) menyatakan bahwa berdasar data Riset Kesehatan Dasar (RISKESDAS) pada 2007 menunjukkan bahwa prevalensi balita kurus sebesar 13,6\%, yaitu 6,2\% termasuk kategori sangat kurus. Hal ini menggambarkan secara jelas tidak ada penurunan prevalensi balita sangat kurus pada 2007 dibandingkan pada 2001.

Faktor yang mempengaruhi timbulnya gizi buruk merupakan faktor yang saling berkaitan baik secara langsung maupun tidak langsung. Prinsip daripada tatalaksana gizi buruk menurut WHO, diadaptasi oleh Departemen Kesehatan RI, terdiri dari 10 langkah yang meliputi tiga fase yaitu stabilisasi, rehabilitasi, dan tindak lanjut (Depkes, 2006).

Cara mengatasi masalah gizi buruk dapat dilakukan melalui pemberian diet untuk meningkatkan berat badan penderita gizi buruk terutama pada anak balita yaitu diet Formula WHO dengan dosis F75 dan F100 (Depkes, 2007). Menurut data dari Dinas Kesehatan Kota Depok, bahwa sampai dengan Februari 2011 tercatat balita yang mengalami gizi buruk 198 balita $(0,16 \%)$ yang sebagian besar berada di daerah tingkat sosial ekonomi rendah yaitu Kampung X dan A Kota Depok.

Hasil survei pendahuluan menjelaskan bahwa data yang didapat dari Puskesmas A jumlah balita yang berada di kedua kelurahan tersebut 214 orang. Pada Desember 2010 teridentifikasi bahwa balita yang mengalami gizi buruk sebanyak 22 orang dengan rincian 10 balita $(45,45 \%)$ di Kelurahan A dan 12 balita $(54,55 \%)$ di Kelurahan B Depok. Program pengelolaan masalah gizi buruk yang sudah dilakukan oleh pihak Puskesmas A yaitu pemberian makanan tambahan (PMT), penyuluhan kesehatan terkait dengan gizi, dan adanya pos gizi.

Berdasarkan penjelasan tersebut, peneliti tertarik untuk menganalisis lebih lanjut pemberian diet formula 75 dan 100 terhadap berat badan balita dengan gizi buruk rawat jalan di wilayah kerja Puskesmas A Kota Depok. Penelitian ini ingin menganalisis lebih lanjut pemberian diet formula 75 dan 100 terhadap berat badan balita dengan gizi buruk rawat jalan, adapun pertanyaan penelitian ini yaitu apakah pemberian diet formula 75 dan 100 dapat berpengaruh terhadap berat badan balita gizi buruk rawat jalan. Penelitian ini bertujuan untuk menjelaskan pengaruh pemberian diet formula 75 dan 100 pada balita yang mengalami gizi buruk rawat jalan.

\section{Metode}

Desain yang digunakan dalam penelitian adalah "quasi experimental pre-post test with control group". Pada penelitian diterapkan total sampling, dimana yang menjadi sampel adalah seluruh balita yang mengalami gizi buruk. Karakteristik sampel yang dilibatkan dalam kriteria inklusi penelitian ini antara lain keluarga dengan balita gizi buruk bersedia menjadi responden dan menandatangani surat persetujuan sebagai responden; balita dengan gizi buruk yang berumur diatas umur $6-59$ bulan; tidak mengalami intoleransi laktosa berdasarkan pemeriksaan dokter; berdomisili di wilayah kerja Puskesmas A, B, C, dan D di Depok; balita gizi buruk tanpa komplikasi; tidak sedang mendapat perawatan TFC (Therapeutic Feeding Center) serta dalam kondisi rawat jalan pada fase stabilisasi, rehabilitasi.

Sampel yang memenuhi kriteria inklusi yang digunakan dalam penelitian ini pada kelompok intervensi berjumlah 16 responden yaitu Puskesmas A dengan rincian 10 responden, dimana sisanya empat responden sudah mengikuti program TFC rawat inap dan dua responden mengalami penyakit komplikasi. Berdasarkan hal ini, untuk melengkapi jumlah sampel pada kelompok intervensi dalam penelitian dipilih Puskesmas B dan teridentifikasi 6 responden memenuhi kriteria sampel penelitian. Pada minggu kedua pelaksanaan intervensi, 1 (satu) responden yang berasal dari Puskesmas A mengundurkan diri (drop out). Hal ini dikarenakan kurang motivasi orangtua untuk mengikuti program sampai dengan selesai sehingga jumlah seluruh sampel kelompok intervesi yaitu 15 responden. 
Kelompok kontrol yang tidak mendapatkan diet formula 75 dan 100 sejumlah 15 responden dengan rincian 6 responden dari Puskesmas D dan 9 responden Puskesmas C.

Etika penelitian yang dilakukan pada responden dalam penelitian ini meliputi informed concent, autonomity, anomymous, confidentiality, justice, honesty, beneficience, dan maleficience. Responden pada kelompok kontrol setelah post test dilakukan koordinasi dengan pihak Puskemas setempat untuk ditindaklanjuti dalam hal pemberian diet formula 75 dan 100 pada balita gizi buruk.

Pengumpulan data dilakukan dengan menggunakan instrumen yang terdiri dari formulir Manajemen Terpadu Balita Sakit (MTBS), kuesioner data karakteristik keluarga (pemberi asuhan), dan alat ukur timbangan berat badan balita. Analisis data yang dilakukan adalah analisis univariat untuk menghitung distribusi frekuensi dan proporsi, analisis bivariat untuk menguji hubungan antara dua variabel yang sebelumnya dilakukan terlebih dahulu uji kesetaraan, dan analisis multivariat ancova. Instrumen yang digunakan penelitian ini untuk mengidentifikasi balita gizi buruk merupakan instrumen baku dari Depkes (2008) yaitu formulir MTBS sehingga tidak dilakukan uji validitas lagi. Uji reliabilitas dengan menggunakan Inter-rater reliability atau reliabilitas antar pengukur dengan metode Cohen's Kappa. Berdasarkan nilai Kappa disimpulkan memiliki kesepakatan baik antara observer 1 dan 2 .

Intervensi berupa pemberian diet formula 75 dan 100 pada balita gizi buruk dilakukan selama 5 minggu. Formula 75 yaitu makanan cair yang mengandung 25 gram susu bubuk skim, 100 gram gula pasir, 30 gram minyak sayur, dan $20 \mathrm{ml}$ larutan elektrolit dalam larutan $1000 \mathrm{ml}$. Formula 100 yaitu makanan cair yang mengandung 85 gram susu bubuk skim, 50 gram gula pasir, 60 gram minyak sayur dan $20 \mathrm{ml}$ larutan elektrolit dalam larutan $1000 \mathrm{ml}$. Penghitungan jumlah kebutuhan energi setiap balita gizi buruk di Puskesmas A berdasarkan tabel petunjuk pemberian formula 75 dan 100 .
Pemberian diet formula 75 dan 100 dilakukan oleh peneliti dan petugas Puskesmas dalam bentuk kemasan dari Puslitbang Gizi Kota Bogor untuk memudahkan keluarga/orangtua saat pemberian kepada balita dengan gizi buruk. Pemantauan BB dilakukan setiap minggu di Puskesmas dengan menggunakan timbangan balita. Selama pemberian intervensi dilakukan monitoring evaluasi berat badan setiap minggu sekali oleh peneliti, kader, dan petugas Puskesmas serta melakukan kunjungan rumah satu minggu sekali.

\section{Hasil}

Pada kedua kelompok mayoritas balita dengan gizi buruk mempunyai jenis kelamin perempuan dan ada penyakit penyerta. Karakterisrik keluarga yang memiliki balita dengan gizi buruk mayoritas berpendidikan rendah dan semua tidak memiliki pekerjaan serta memiliki hubungan dengan klien sebagai orangtua. Rerata berat badan balita dengan gizi buruk rawat jalan pada kelompok intervensi sebelum diberikan diet formula 75 dan 100 sebesar 7253 gram. Pada kelompok intervensi didapat rerata berat badan balita sesudah lima minggu perlakuan menunjukkan peningkatan 506,67 gram. Pada kelompok kontrol tidak dilakukan evaluasi berat badan setiap minggu tetapi hanya diukur sebelum dan sesudah perlakuan sesuai dengan desain penelitian quasi experimental pre-post test with control group.

Hasil uji statistik karakteristik balita dengan gizi buruk serta berat badan sebelum pada kelompok intervensi dan kontrol memiliki kesetaraaan pada usia, jenis kelamin, dan penyakit penyerta, bahwa tidak terdapat perbedaan yang bermakna proporsi antara kedua kelompok $(p>\alpha)$. Karakteristik keluarga untuk pendidikan juga menunjukkan hasil tidak terdapat perbedaan yang bermakna tingkat pendidikan antara kelompok intervensi dan kontrol. Uji normalitas pada variabel berat badan sebelum dan sesudah pada kelompok intervensi dan kontrol, selisih berat badan sebelum dan sesudah pada kelompok intervensi dan kontrol berdistribusi normal. 
Pada kelompok intervensi nilai rerata berat badan sesudah pemberian diet formula 75 dan $100(7760$ gram) lebih besar dibandingkan sebelum (7253 gram). Hasil disimpulkan bahwa ada perbedaan berat badan sebelum dan sesudah perlakuan yang bermakna pada kelompok intervensi $(p=0,00 ; \alpha=$ 0,05). Pada kelompok kontrol nilai rerata berat badan sesudah (7993 gram) lebih besar dibanding sebelum (7913 gram). Terdapat perbedaan berat badan sebelum dan sesudah yang bermakna pada kelompok kontrol $(p=0,008 ; \alpha=0,05)$.

Rerata berat badan sebelum diberikan diet formula 75 dan 100 terdapat perbedaan pada kedua kelompok yaitu kelompok intervensi 7253 gram sedangkan kelompok kontrol 7913 gram. Hasil uji menunjukkan bahwa tidak terdapat perbedaan berat badan sebelum pemberian diet formula 75 dan 100 yang bermakna antara kelompok intervensi dan kelompok kontrol $(p=0,24 ; \alpha=0,05)$.

Rerata berat badan setelah diberikan diet formula 75 dan 100 ada perbedaan pada kedua kelompok yaitu kelompok intervensi 7760 gram, sedangkan pada kelompok kontrol 7993 gram. Hasil uji menunjukkan bahwa tidak terdapat perbedaan pada berat badan sesudah pemberian formula 75 dan 100 yang bermakna antara kelompok intervensi dan kelompok kontrol $(p=0,68 ; \alpha=0,05)$.

Rerata selisih berat badan sebelum dan sesudah diberikan formula 75 dan 100 terdapat perbedaan pada kedua kelompok yaitu kelompok intervensi (506,67 gram) lebih besar dibandingkan dengan kelompok kontrol (80 gram). Hasil uji disimpulkan terdapat perbedaan selisih berat badan sebelum dan setelah diberikan diet formula 75 dan 100 yang bermakna antara kelompok intervensi dan kontrol $(p=0,00 ; \alpha=0,05)$.

Hasil uji Ancova dapat disimpulkan bahwa hanya variabel jenis perlakuan (variabel independen) yang bermakna mempengaruhi berat badan balita gizi buruk (variabel dependen) $(p=0,00 ; \alpha=0,05)$. Keempat variabel confounding tidak bermakna mempengaruhi berat badan balita $(\mathrm{p}>0,05)$.

\section{Pembahasan}

Karakteristik responden rerata usia balita yang mengalami gizi buruk pada kelompok intervensi yaitu 24 bulan, sedangkan pada kelompok kontrol yaitu 25 bulan. Menurut Supariasa, Bakri, dan Fajar (2002) menjelaskan bahwa angka kejadian gizi buruk pada usia ini sering terjadi karena pada usia ini merupakan periode penyapihan. Wong (2001) menjelaskan bahwa anak usia toddler yaitu 1-3 tahun merupakan tahun pertama tahap tumbuh kembang setelah anak normal melalui masa bayi.

Kebutuhan nutrisi anak usia toddler sebagian besar mengalami periode berkurangnya nafsu makan yang dikenal dengan anoreksia fisiologis. Menurut Depkes (2001), bahwa proporsi tertinggi anak balita dengan gizi buruk sering terjadi pada kelompok usia 12-23 bulan. Hasil analisis menunjukkan tidak terdapat perbedaan usia yang bermakna antara kelompok intervensi dan kelompok kontrol. Hasil pada penelitian tersebut berbeda dengan penjelasan secara teori, hal ini disebabkan kasus gizi buruk dapat terjadi dalam berbagai rentang usia anak.

Mayoritas jenis kelamin balita gizi buruk baik pada kelompok intervensi maupun kelompok kontrol adalah perempuan. Menurut Jellife (1989 dalam Supariasa, et al., 2002), seks atau jenis kelamin merupakan faktor internal yang mempengaruhi pertumbuhan dimana laki-laki lebih panjang dan berat. Hasil penelitian Hasbi (2007) menjelaskan jenis kelamin balita KEP mayoritas adalah laki-laki. Hasil analisis menunjukkan bahwa tidak terdapat perbedaan jenis kelamin yang bermakna antara kedua kelompok. Hasil penelitian tersebut berbeda dengan penjelasan secara teori, hal ini disebabkan variasi karakteristik jenis kelamin yang sama pada kedua kelompok menunjukkan jenis kelamin tidak akan mempengaruhi berat badan balita gizi buruk setelah perlakuan.

Penyakit penyerta tersebar merata pada kedua kelompok. Hampir semua anak dengan gizi buruk menderita penyakit infeksi. Menurut UNICEF (1998, dalam Soekirman, 1999), penyakit infeksi dan gizi buruk mempunyai hubungan yang sinergis. 
Menurut Kardjati dan Alisjahbana (1985), penyakit infeksi berawal dari kemiskinan dan lingkungan tidak sehat dengan sanitasi buruk dan penyakit infeksi juga dapat menghambat reaksi imunologis yang normal dengan menghabiskan sumber-sumber energi di tubuh.

Hasil analisis menunjukkan bahwa tidak terdapat perbedaan penyakit penyerta yang bermakna antara kedua kelompok. Hasil penelitian tersebut berbeda dengan penjelasan secara teori, hal ini disebabkan adanya proporsi anak yang menderita penyakit infeksi tersebar merata sehingga menunjukkan penyakit penyerta tidak akan mempengaruhi berat badan balita gizi buruk setelah perlakuan. Menurut analisa peneliti bahwa balita yang mengalami gizi buruk dapat disebabkan adanya kondisi kesehatan dan kebersihan lingkungan yang kurang.

Mayoritas pendidikan keluarga kedua kelompok adalah SD atau pendidikan rendah. Soetjiningsih (1995) memaparkan bahwa pendidikan orangtua merupakan salah satu faktor yang penting dalam pertumbuhan dan perkembangan anak. Hal tersebut sangat penting karena dengan pendidikan yang baik, maka orangtua dapat menerima segala informasi dari luar terutama dalam memberikan pemenuhan kebutuhan nutrisi pada anak sesuai dengan tahapan usianya. Hasil analisis pada pendidikan keluarga menunjukkan tidak terdapat perbedaan yang bermakna tingkat pendidikan pada kedua kelompok. Hal ini menjelaskan bahwa peningkatan berat badan balita dengan gizi buruk rawat jalan yang terjadi pada kelompok intervensi disebabkan pemberian diet formula 75 dan 100 .

Rerata berat badan balita gizi buruk sebelum dan sesudah pemberian formula 75 dan 100 pada kelompok kontrol lebih besar daripada kelompok intervensi. Hal ini terjadi dikarenakan proporsi karakteristik berbeda dan bervariasi pada kedua kelompok, usia 7-48 bulan, sehingga berpengaruh pada berat badan. Namun, terjadi kecenderungan peningkatan rerata berat badan balita gizi buruk pada kelompok intervensi lebih besar daripada kelompok kontrol. Apabila dianalisis lebih lanjut, nilai selisih rerata berat badan balita gizi buruk pada kedua kelompok menunjukkan hasil berbeda. Hasil penelitian menjelaskan terdapat perbedaan selisih berat badan sebelum dan sesudah perlakuan secara bermakna antara kedua kelompok. Pada kelompok intervensi, rerata selisih berat badan sebelum dan sesudah diberi formula 75 dan 100 lebih besar dibanding dengan kelompok kontrol.

Penerapan model teori Johnson terhadap asuhan keperawatan balita gizi buruk rawat jalan selama proses penelitian merupakan suatu kondisi yang dipengaruhi oleh stresor negatif dari luar. Subsistem yang terganggu pada kondisi balita dengan gizi buruk rawat jalan diantaranya yaitu hubungan kasih sayang/perhatian antara anak dengan orangtua. Balita gizi buruk selama upaya pemulihan perlu perawatan serta pendampingan secara optimal berupa dukungan secara psikologis.

Subsistem dependensi dijelaskan sebagai kondisi dimana balita memerlukan respon pengasuhan dari orangtua dalam hal bantuan dan perhatian. Hal ini sesuai pendapat George (1995), yang menjelaskan subsistem ketergantungan lebih memperhatikan pada tempat atau lingkungan, yaitu klien memenuhi segala kebutuhannya. Apabila dianalisis lebih jauh maka dapat disimpulkan bahwa pada kondisi balita gizi buruk membutuhkan dan melibatkan peran serta keluarga sebagai sistem pendukung dalam mengembalikan fungsi hidup secara biologis.

Hasil uji analisis data menunjukkan bahwa hanya variabel jenis perlakuan (variabel independen) yang bermakna mempengaruhi berat badan balita dengan gizi buruk (variabel dependen). Keempat variabel confounding tidak bermakna mempengaruhi berat badan balita gizi buruk. Hasil penelitian didapat jenis perlakuan berkontribusi $85,5 \%$ terhadap selisih berat badan balita gizi buruk rawat jalan. Hal ini menunjukkan diet formula 75 dan 100 terbukti efektif dalam meningkatkan berat badan balita gizi buruk rawat jalan. Arnelia, Lamid, dan Rachmawati (2011) meneliti tentang pemulihan gizi buruk rawat jalan dapat memperbaiki asupan energi dan status gizi anak usia di bawah 3 tahun. 
Keterkaitan penatalaksanaan kasus balita dengan gizi buruk pada penelitian ini dengan model teori perilaku Johnson fokus pada gangguan subsistem biologis, seksual, agresif, dan achievement. Model sistem perilaku Johnson ini terdiri dari berbagai subsistem yang saling mempengaruhi status gizi balita khususnya dalam mengidentifikasi masalah gizi buruk. Intervensi keperawatan pada balita gizi buruk rawat jalan dapat dilakukan melalui tindakan kolaboratif dengan pemberian diet formula 75 dan 100 untuk meningkatkan berat badan.

Hasil akhir intervensi yang dilakukan selama proses penelitian yaitu adanya peningkatan berat badan balita gizi buruk rawat jalan sehingga disimpulkan program/upaya yang dilakukan telah berhasil. Keterlibatan orangtua selama penatalaksanaan balita gizi buruk rawat jalan yaitu dalam melakukan monitoring pemberian diet formula 75 dan 100 di rumah. Hal ini sesuai dengan penjelasan menurut Johnson, stresor internal melibatkan 3 hal penting yaitu faktor biologis, psikologis, dan sosial.

\section{Kesimpulan}

Hasil penelitian menunjukkan terdapat perbedaan rerata berat badan balita gizi buruk sebelum dan sesudah mendapatkan diet formula 75 dan 100 yaitu 506,67 gram. Terdapat perbedaan rerata berat badan balita dengan gizi buruk pada kelompok yang tidak mendapatkan diet formula 75 dan 100, tapi hanya diberikan makanan tambahan (PMT) yaitu 80 gram. Terdapat perbedaan selisih rerata berat badan antara sebelum dan sesudah perlakuan antara kelompok intervensi dan kontrol. Kelompok intervensi yang mendapatkan diet formula 75 dan 100 mampu meningkatkan berat badan pada balita gizi buruk rawat jalan lebih besar dibanding dengan kelompok kontrol. Variabel perancu (confounding) dalam penelitian ini (umur balita, jenis kelamin balita, penyakit penyerta dan pendidikan keluarga) tidak berkontribusi terhadap berat badan balita gizi buruk rawat jalan. Bagi puskesmas diharapkan dapat menindaklanjuti hasil penelitian ini agar mencapai target berat badan balita gizi buruk rawat jalan sesuai dengan standar (HW, ENN, HP).

\section{Referensi}

Arnelia, Lamid, S., \& Rachmawati, R. (2011). Pemulihan gizi buruk rawat jalan dapat memperbaiki asupan energi dan status gizi pada anak usia dibawah tiga tahun. Jurnal Gizi Klinik Indonesia, 7 (3), $105-111$.

Departemen Kesehatan RI. (2001). Studi kesehatan ibu dan anak. Jakarta: Departemen Kesehatan RI.

Departemen Kesehatan RI. (2006). Buku bagan tatalaksana anak gizi buruk. Jakarta: Departemen Kesehatan RI.

Departemen Kesehatan RI. (2007). Petunjuk teknis tatalaksanan anak gizi buruk. Jakarta: Departemen Kesehatan RI.

Departemen Kesehatan RI. (2008). Buku bagan manajemen terpadu balita sakit (MTBS). Jakarta: Departemen Kesehatan RI.

George, J.B. (1995). Nursing theories: The base for professional nursing practice (4th Ed.). Norwalk: Appleton \& Lange.

Hasbi, M. (2007). Faktor-faktor yang berhubungan dengan kekurangan energi protein (KEP) pada balita di Kecamatan Batu Layar Kabupaten Lombok Barat (Skripsi, tidak dipublikasikan). Universitas Diponegoro, Semarang - Jawa Tengah.

Kardjati, S., \& Alisjahbana, S. (1985). Aspek kesehatan \& gizi anak balita. Jakarta: Yayasan Obor Indonesia.

Sajudi, A. (2000). Sambutan dalam rencana aksi-aksi pangan \& gizi nasional. Jakarta: Pemerintah RI bekerjasama dengan World Health Organization.

Soekirman. (2000). Ilmu gizi \& aplikasinya. Jakarta: Penerbit Buku Kedokteran EGC.

Soetjiningsih. (1995). Tumbuh kembang anak. Jakarta: Penerbit Buku Kedokteran EGC.

Supariasa, I.D.N., Bakri, B., \& Fajar, I. (2002). Penilaian status gizi. Jakarta: Penerbit Buku Kedokteran EGC.

Wong, D.L. (2001). Wong's essential of pediatric nursing (6th Ed.). St. Louis: Mosby. 